\title{
Biocontrol traits of Bacillus licheniformis GL174, a culturable endophyte of Vitis vinifera cv. Glera
}

\author{
Sebastiano Nigris ${ }^{1}$, Enrico Baldan², Alessandra Tondello², Filippo Zanella ${ }^{2}$, Nicola Vitulo ${ }^{3}$, Gabriella Favaro ${ }^{4}$ \\ Valerio Guidolin², Nicola Bordin², Andrea Telatin ${ }^{5}$, Elisabetta Barizza², Stefania Marcato², Michela Zottini ${ }^{2}$, \\ Andrea Squartini ${ }^{6}$, Giorgio Valle ${ }^{2}$ and Barbara Baldan ${ }^{1 *}$
}

\begin{abstract}
Background: Bacillus licheniformis GL174 is a culturable endophytic strain isolated from Vitis vinifera cultivar Glera, the grapevine mainly cultivated for the Prosecco wine production. This strain was previously demonstrated to possess some specific plant growth promoting traits but its endophytic attitude and its role in biocontrol was only partially explored. In this study, the potential biocontrol action of the strain was investigated in vitro and in vivo and, by genome sequence analyses, putative functions involved in biocontrol and plant-bacteria interaction were assessed.

Results: Firstly, to confirm the endophytic behavior of the strain, its ability to colonize grapevine tissues was demonstrated and its biocontrol properties were analyzed. Antagonism test results showed that the strain could reduce and inhibit the mycelium growth of diverse plant pathogens in vitro and in vivo. The strain was demonstrated to produce different molecules of the lipopeptide class; moreover, its genome was sequenced, and analysis of the sequences revealed the presence of many protein-coding genes involved in the biocontrol process, such as transporters, plant-cell lytic enzymes, siderophores and other secondary metabolites.

Conclusions: This step-by-step analysis shows that Bacillus licheniformis GL174 may be a good biocontrol agent candidate, and describes some distinguished traits and possible key elements involved in this process. The use of this strain could potentially help grapevine plants to cope with pathogen attacks and reduce the amount of chemicals used in the vineyard.
\end{abstract}

Keywords: Grapevine, Endophytes, Biocontrol bacteria, Bacillus licheniformis, Bacterial genome sequencing

\section{Background}

Biological control is an increasingly successful and widespread strategy [1] to decrease plant pathogens and the negative effects of agricultural practices on the environment. It uses beneficial microorganisms, either bacteria or fungi, that can counteract plant pathogens and limit the use of chemicals in agriculture [2]. Among these diverse beneficial microorganisms, bacterial endophytes are powerful tools to protect plants from phytopathogens due to their ability to enter and colonize plants.

\footnotetext{
* Correspondence: barbara.baldan@unipd.it

${ }^{1}$ Botanical Garden and Department of Biology, University of Padova, Padova, Italy

Full list of author information is available at the end of the article
}

Endophytes are bacteria that can live inside plant tissues and colonize their hosts without causing any signs of plant disease. They penetrate plants mainly from the soil and roots and spread into leaves, flowers and fruits through the vascular plant system [3, 4]. These bacteria spend part of (facultative endophytes) or all (obligate endophytes) their life-cycle inside plants, exploiting this strategic interaction to their advantage $[3,5]$. They may both promote the growth of plants and protect them against harmful bacteria and fungi. Endophytes can enhance plant-growth rate and biomass production largely through phytohormone synthesis, nitrogen fixation, phosphate solubilization and ammonium ion production. They protect hosts as biocontrol agents by interacting

(C) The Author(s). 2018 Open Access This article is distributed under the terms of the Creative Commons Attribution 4.0 International License (http://creativecommons.org/licenses/by/4.0/), which permits unrestricted use, distribution, and 
directly with pathogens and producing many antimicrobial molecules, and/or by competing for nutrients inside the colonized tissues [3, 6]. Biocontrol bacteria also act indirectly, eliciting Induced Systemic Resistance (ISR) in their plant hosts: a plethora of metabolites produced by endophytes activates plant defense priming responses against pathogens [7].

Many endophyte taxa produce lipopeptides (LPs) - molecules that play a crucial role in biocontrol acting directly as antimicrobial/antifungal compounds and as ISR elicitors in plant hosts. These amphiphilic compounds are formed by a short cyclic oligopeptide linked to a lipid tail [8]. The most widely studied LPs belong to the surfactin, iturin and fengycin families, according to their chemical structure. Surfactins are heptapeptides interlinked with a $\beta$-hydroxy fatty acid to form a cyclic lactone ring; due to their strong biosurfactant activity, these molecules can readily associate and anchor themselves to the double layer of phospholipids interfering with membrane integrity. Iturins are heptapeptides bound to a $\beta$-amino fatty acid chain 14-17 carbons long. Fengycins are lipodecapeptides with an internal lactone ring in the peptidic moiety and a $\beta$-hydroxy fatty acid chain (C14-C18) that may be saturated or unsaturated [9]. These molecules, according to their chemical characteristics, fight bacteria, fungi, mycoplasmas and viruses. Due to their strong surfactant power, LPs enable and favor plant colonization by the producer strain hindering pathogenic tissue infection. Bacteria synthesize these families of lipopeptides in a non-ribosomal way through large enzymatic complexes, namely, lipopeptide synthetases. These mega-enzymes are organized in iterative modules that catalyze reactions for lipopeptide production.

Visualization of bacteria inside plants is always difficult as plant tissues are complex and autofluorescent. Recently, molecular techniques employing fluorescent probes that detect bacteria via hybridization have been used to localize and estimate microorganisms within plant organs $[4,10]$. Inoculation with strains tagged with green fluorescent protein (GFP) and glucuronidase gene markers has enabled scientists to observe live bacteria inside tissues, which is particularly useful when following bacterial colonization patterns and estimating endophytic populations [11-13]. GFP-tagged bacteria are handy tools to examine endophyte-plant interactions [14], as GFP does not require any substrate or cofactor to fluoresce. GFP cassettes for chromosomal integration and expression of the reporter gene in many bacterial species have been developed [15-17]. The transformation of bacteria with plasmids harboring integrative cassettes leads to more stable tagged strains, because the chromosomal insertion is less subjected to selective pressure [15]. Recent studies have demonstrated that grapevine cv. chardonnay is efficiently colonized by Burkholderia phytofirmans PsJN::gfp2x; it colonizes roots, stems and leaves, showing how GFP-tagged strains may be used even to check grapevine colonization [12].

An important characteristic of endophytes is to secrete into the environment lytic enzymes that degrade many biological polymers. Such enzymes, in particular cellulose-lytic enzymes, favor the entrance of endophytes into plant tissues and the formation of stable colonies, giving clear competitive advantage to bacteria with this ability [18]. Before evaluating biocontrol effects, and to develop bacteria inocula for agriculture, it is essential to show if and how a particular strain colonizes inner plant tissues.

In this work, the culturable strain GL174, previously isolated from Vitis vinifera cv. Glera [19] was investigated to identify both its endophytic ability and some of its biocontrol traits. GL174 was selected from a collection of putative grapevine endophytes for its plant-growth promotion abilities. Moreover, GL174 can produce ammonia and the plant hormone indole-3-acetic acid, and causes morphological changes to the plant roots when co-cultured with Arabidopsis thaliana [20]. The strain was identified as $\mathrm{Ba}$ cillus licheniformis GL174 and its endophytic attitude was validated by plating surface-sterilized inoculated cuttings. Then, using confocal microscopy, we localized the GFP-tagged strain within plant tissues of inoculated grapevine Glera cuttings. Visualization of tagged bacteria inside plant structures allowed us to identify the examined strain as a true endophyte of the plants, and provided a reliable protocol for cutting inoculation for further biocontrol experiments. As the plant growth-promoting (PGP) abilities of strain GL174 had already been demonstrated [20], we focused on its potential biocontrol activity and antifungal properties. We reported both antifungal activity against some grapevine fungal pathogens by an in vitro bioassay and in vivo on grapevine leaves. Furthermore, we reported an effective production of LPs, detected by mass spectrometric analyses and we also sequenced the entire genome. The results of this multidisciplinary approach enabled us to assess the complex pattern of biocontrol traits displayed by Bacillus licheniformis GL174.

\section{Methods}

\section{Bacterial strain and growth conditions}

The strain GL174 was previously isolated from surface-sterilized tissues of Vitis vinifera cv. Glera and identified as Bacillus licheniformis [19]. This strain was cultivated routinely in Nutrient Broth (NB) or Nutrient Agar (NA) at $28^{\circ} \mathrm{C}$.

\section{Grapevine cutting re-inoculation for endophytic proficiency validation}

Sterile stem cuttings of grapevine cultivar Glera, approximately $20 \mathrm{~mm}$ long, each bearing an axillary bud, were obtained from in vitro plants grown in Murashige and Skoog (MS) solid medium. The GL174 strain was 
grown overnight in $\mathrm{NB}$ medium at $28{ }^{\circ} \mathrm{C}$ under shaking. Cells were harvested by centrifugation at $1500 \times g$ and resuspended in sterile $10 \mathrm{mM} \mathrm{MgSO}_{4}$ with a final optical density of 0.1 . The lower extremity of each cutting was dipped for 1 min into the bacteria suspension. Negative controls were performed by dipping cuttings into sterile $\mathrm{MgSO}_{4}$. Inoculated cuttings were cultivated in MS/2 solid medium, without sugar, at $24{ }^{\circ} \mathrm{C}$, with $25 \mu \mathrm{mol} \mathrm{m}-2 \mathrm{~s}-1$ light intensity and a photoperiod of $8 \mathrm{~h}$ of light and $16 \mathrm{~h}$ of dark. Four weeks after cutting inoculation, the presence of GL174 bacteria inside the plants was tested. Sections of plant stems of each cutting were treated to extract endophytes, as previously described. Three different dilutions of the ground plant material were plated onto NA medium and incubated at $28{ }^{\circ} \mathrm{C}$ for $48 \mathrm{~h}$ [19]. After this preliminary indication, the endophytic colonization of Glera cuttings by GL174 was assessed using a GFP-tagged strain, GL174::gfp, and laser scanning confocal microscopy.

\section{Transformation of Bacillus licheniformis GL174}

Plasmid pUTgfp $2 \mathrm{X}$ contains a mini-Tn5 transposon delivery system, a PpsbA-RBS- $g f p 2 \mathrm{X}$ cassette: two $g f p$ genes, repeated in tandem, plus the additional $35 \mathrm{bp}$ region containing the Ribosome Binding Site, located downstream the constitutive $p s b A$ promoter [15].

Bacteria were grown in NA plates added with $50 \mathrm{mg} / \mathrm{L}$ Kanamycin for 1 week at $28{ }^{\circ} \mathrm{C}$. In order to transform the strain, electroporation was performed following a modified protocol from Xue et al., [21]. A colony was inoculated in $5 \mathrm{~mL}$ of NB $0.5 \mathrm{M}$ sorbitol and grown until it reached $0.9 \mathrm{OD}_{600}$. Cells were cooled in ice and centrifuged at $4000 \mathrm{~g}$ for $10 \mathrm{~min}$ at $4{ }^{\circ} \mathrm{C}$. Bacteria were resuspended in $1 \mathrm{~mL}$ and washed 3 times with $500 \mu \mathrm{L}$ of cold electroporation medium (10\% glycerol, $0.5 \mathrm{M}$ sorbitol and $0.5 \mathrm{M}$ mannitol). After washing, cells were resuspended in $60 \mu \mathrm{L}$ of electroporation medium and mixed with $2 \mu \mathrm{L}$ of pUTgfp2X plasmid $(389 \mathrm{ng} / \mu \mathrm{L})$. Bacteria were incubated $10 \mathrm{~min}$ in ice and transferred in pre-chilled electroporation cuvettes. They were electroporated using a Gene-Pulser (Bio-Rad Laboratories, Richmond, CA) set at $2.5 \mathrm{kV}, 200 \Omega$ with a resulting time constant of $4.5-$ $5.4 \mathrm{~ms}$. Immediately after electroporation, $1 \mathrm{~mL}$ of $\mathrm{NB}$ was added to the transformed cells; then bacteria were incubated at $28{ }^{\circ} \mathrm{C}$ under shaking for $3 \mathrm{~h}$. After incubation, 100,200 and $300 \mu \mathrm{L}$ of bacteria were plated on NA solid medium supplemented with $30 \mathrm{mg} / \mathrm{L}$ Kanamycin and incubated at $28{ }^{\circ} \mathrm{C}$. The resulting colonies were analyzed under a fluorescence stereomicroscope (excitation at $488 \mathrm{~nm}$ ) to check bacteria fluorescence.

\section{Inoculation of Glera cuttings with Bacillus licheniformis GL174::gfp2x}

The ability of these strains to colonize and survive within Glera tissues was investigated inoculating cuttings and analyzing the plants by Laser Scanning Confocal Microscopy (LSCM). We used apical cuttings with 2 leaves obtained from 1 month-old plants grown in vitro. One fluorescent colony was inoculated in NB with $30 \mu \mathrm{g} / \mu \mathrm{L}$ of kanamycin and grown overnight. Bacteria was centrifuged and resuspended in $5 \mathrm{~mL}$ of $\mathrm{MgSO}_{4}$ $10 \mathrm{mM}$. The optical density of the suspension was measured and bacteria were diluted with the same buffer to a cell density of $10^{6}$ cells $/ \mathrm{mL}$. One drop $(5 \mu \mathrm{L})$ of the suspension was placed on the surface of the solid medium MS half-concentrated [22] contained in a vented Magenta box. In correspondence of the drop, one apical cutting was planted in the medium. As negative control, 3 cuttings were inoculated only with $\mathrm{MgSO}_{4}$ buffer. In order to check colonization, we inoculated 6 plants for each strain: 3 cuttings were sampled 30 days after inoculation. Stem samples were $3 / 4 \mathrm{~cm}$ long, inclusive from the inoculation point and the first node. One control plant was also analyzed to control the absence of any fluorescence bacteria inside the tissues.

\section{Laser scanning confocal microscopy of inoculated Glera tissues}

Stem explants were first surface-sterilized for 2 min with sodium hypochlorite $1 \%$, rinsed with $70 \%$ ethanol and then washed 3 times for $10 \mathrm{~min}$ with sterile deionized water. Stems and roots were sliced longitudinally with a blade, and leaf fragments were observed directly. Plant explants were mounted on a slide with a solution of $50 \%$ glycerol and covered with a coverslip. Confocal laser scanning microscopy was performed with a Leica SP5 system using an excitation laser of $488 \mathrm{~nm}$ (Argon laser) and collecting the emission band of $515-560 \mathrm{~nm}$ for GFP fluorescence and of 695-765 nm for chlorophyll fluorescence.

\section{In vitro antifungal effects of endophytic bacteria}

The evaluation of in vitro antifungal effects was performed testing strain GL174 against some grapevine-pathogenic fungi like Phaeoacremonium aleophilum, Phaeomoniella spp, Botryosphaeria spp, Botrytis cinerea and more generic plant pathogens Sclerotinia sclerotiorum and Phytophthora infestans. The endophyte was streaked horizontally in the middle of a Petri dish with PCA medium; plates were incubated at $28{ }^{\circ} \mathrm{C}$ for $48 \mathrm{~h}$ to obtain bacterial growth. After bacterial growth, two inocula of fungal mycelium were placed on the same plate, one on the right and one on the left of the endophyte. Plates with both bacteria and fungi were incubated for one week at $28{ }^{\circ} \mathrm{C}$. High-resolution pictures (600 dpi) of the plates were obtained and the antifungal effect of the bacterium was evaluated comparing the inhibition of mycelium expansion in the presence of the endophyte strain, and measuring the mycelium radius in 
the direction of the bacterium using photo-editing software. For each plate we calculated the average radius of the mycelia using the following equation: $\mathrm{Rm}$ $=((\mathrm{R} 1-\operatorname{Rin})+(\mathrm{R} 2-\mathrm{Rin})) / 2$, where Rin is the fungal inoculum radius. An inhibition index was calculated as percentage of reduction of fungal growth comparing $\mathrm{Rm}$ and the mycelium radius of control plates containing fungi without bacteria.

\section{In vivo antagonism assay}

The biocontrol activity against Botrytis cinerea was tested using two sets of plants: the first set was represented by 60 day-old plants in soil pots and the second one by 60 day-old plants inoculated with GL174 when propagated as cuttings (see above the described inoculation protocol); to mime the endophyte colonization and check their direct effect, the abaxial sides of leaves were infiltrated with a $10^{3}$ cells $/ \mathrm{mL}$ bacteria suspension (in $10 \mathrm{mM} \mathrm{MgSO}_{4}$ buffer) by means of a syringe without needle; as negative control some leaves were injected with sterile $\mathrm{MgSO}_{4}$ buffer. On these two groups of plants, the antagonism tests were performed on detached leaves [23] and on leaves in planta.

In the first test, detached fully expanded leaves from plants, both those infiltrated with GL174 and those from previously GL174-inoculated plants, were placed on wet paper and were challenged by placing a mycelial plug (diameter $10 \mathrm{~mm}$ ) of Botrytis cinerea, collected from a 7-day-old PDA plate, on the middle of the leaves. The trays with the challenged leaves were covered to keep a high relative humidity for the fungus development.

In the second test, leaves of the plants, both those infiltrated with GL174 and those from previously GL174-inoculated plants, were challenged in planta with mycelial plugs as described above. Plants were kept in plastic bags in a growth chamber.

Non-treated leaves were included in all the experimental conditions: not infiltrated leaves and leaves from not inoculated plants were challenged with the fungus. Negative controls were also set providing sterile medium plugs to the leaves to check any detrimental effect of the inoculation method independently from the fungus.

The effects of the fungus infection on every set of treated leaves were evaluated after 1 week of infection collecting pictures of the leaves and measuring the surface of the brown lesions by means of the software ImageJ. The mean of the values recorded on bacterized leaves was compared with the mean of the surface values obtained by non-treated leaves. Five plants were used in each treatment: for each treatment three/four leaves were used and data are expressed as damaged area $\left(\mathrm{cm}^{2}\right)$ and asterisks indicate statistically significant differences among treatments ( $\mathrm{T}$ student test; $p=0.05$ ).

\section{Liquid chromatographic-mass spectrometric analysis}

Strain GL174 was analyzed in liquid culture for production of lipopeptides. To obtain the crude extract of LPs, bacteria were inoculated in $500 \mathrm{~mL}$ of $\mathrm{NB}$, and grown for $96 \mathrm{~h}$ at $28{ }^{\circ} \mathrm{C}$ under shaking. Bacteria were removed by centrifugation at $4000 \mathrm{~g}$ for $20 \mathrm{~min}$. The supernatant was acidified to $\mathrm{pH} 2$ with $6 \mathrm{~N} \mathrm{HCl}$. A white precipitate was obtained and collected by centrifugation at $8000 \mathrm{~g}$. The supernatant was discarded and the solid precipitate extracted with $10 \mathrm{~mL}$ of methanol using the volume ratio solid-solvent $1: 2$. Suspensions were stored at $4{ }^{\circ} \mathrm{C}$ for $1 \mathrm{~h}$ and the clear methanol phase was transferred into a vial for the electrospray ionization mass spectrometry (ESI-MS) analysis [24, 25].

\section{Genome sequencing and sequence analysis}

Genomic DNA of Bacillus licheniformis GL174 was extracted using UltraClean ${ }^{\circ}$ Microbial DNA Isolation Kit (MoBio, Solana Beach CA, USA) from $5 \mathrm{~mL}$ of an overnight culture. Afterwards, Genomic DNA was fragmented and sequenced using ION Proton (Life technologies $\odot$ ) sequencing technology. Genome assembly was performed with the Newbler program.

Sequencing data, assembly and gene prediction were submitted to a public database and are available at BioProject database (http://www.ncbi.nlm.nih.gov/bioproject/) with accession number PRJNA274883. The gene annotation process was performed using the annotation pipeline implemented in the BASys bacterial annotation system (https://www.basys.ca/) so that all the coding sequences were assigned to a COG (Cluster of Orthologs) functional class. In addition, the identified coding sequences were compared with the InterPro database (https://www.ebi.ac.uk/interpro/) for double annotation of the protein functions. Among all the identified protein functions, we isolated the sequences related to chemotaxis and motility, plant wall degrading enzymes and plant colonization, iron nutrition and metabolism, phosphate nutrition and metabolism, nitrogen uptake and metabolism, lipopeptides and other secondary metabolites biosynthesis and oxidative stress response.

\section{Results}

Strain GL174 can colonize Glera cuttings grown in gnotobiotic conditions

Grapevine Glera cuttings from sterile micro-propagated plants were used to check how Bacillus licheniformis GL174 strain colonizes and spreads inside plant tissues. After one month, no bacteria were isolated from control plants, confirming the absence of culturable endophytes in non-inoculated cuttings. We re-isolated the same strain from stems of the in vitro inoculated cuttings $\left(5.66 \pm 0.21 \log _{10} \mathrm{CFU} / \mathrm{g} F W\right)$ and obtained a preliminary indication that the Glera plant inner tissues of the stem 
were colonized, and that GL174 is a true endophyte of Glera grapevine.

Analysis of kanamycin resistance demonstrated that Bacillus licheniformis GL174 is not resistant to kanamycin: no colonies were detected on NA supplemented with $50 \mathrm{mg} / \mathrm{L}$ kanamycin. This result prompted us to use a plasmid bearing a Kanamycin resistance cassette as selective marker. Transformation of Bacillus licheniformis GL174 with pUTgfp2x provided a fluorescent strain, comparable with the wild type for both growth rate and colony morphology. The GFP-tagged strain was used to follow bacteria inside Vitis vinifera Glera and verify that the strain could recolonize plant tissues and thrive within them.

After 30 days, cuttings inoculated with the strain appeared healthy and without any signs of disease-related infection (Fig. 1a and b). We examined longitudinal stem sections (taken at $4 \mathrm{~cm}$ from the inoculation point) of three plants and detected bacteria by harvesting their fluorescence inside the stem, mainly located within xylem vessels (Fig. 2a-d).

\section{Bacillus licheniformis GL174 inhibits mycelium growth of some grapevine pathogenic fungi}

Bacillus licheniformis GL174 was challenged to determine in vitro antifungal effects against some pathogenic grapevine fungi: Phaeoacremonium aleophilum (Fig. 3a, b), Botryosphaeria spp (Fig. 3c, d), Botrytis cinerea (Fig. 3e, f), and against two more generic plant pathogens: Phytophtora infestans (see Additional file 1A, B), and Sclerotinia sclerotiorum (see Additional file 1C, D). The antagonistic effect of the strain was quantified by measuring the mycelium radius. Except for Phytophtora infestans, all pathogen growth was reduced in the presence of the endophyte; mycelium expansion was inhibited by over $60 \%$ compared with the negative controls in which mycelia grew without any antagonist bacteria (Table 1).

\section{Bacillus licheniformis GL174 reduces Botrytis cinerea mycelium growth on grapevine leaves}

The antagonism test on detached and in planta grapevine leaves revealed the biocontrol attitude of the examined strain. Detached leaves, infiltrated with strain GL174, showed a significant reduction of the necrotic pathogen-induced area (Fig. 4a) whereas the fungus effect on leaves from two month-old GL174 inoculated plants was comparable with that observed on not bacterized plants (Fig. 4b). In planta both GL174 infiltrated leaves and leaves from two month-old GL174 inoculated plants displayed a sharp reduction of area with symptoms compared to non treated plants (Fig. $4 \mathrm{c}$ and d).

\section{Mass spectrometry analysis of GL174 culture supernatant reveals the production of LPs}

Considering the results obtained from in vitro and in vivo antagonism assays and from genome analysis indications, the production of LPs in GL174 culture medium was investigated by mass spectrometry analysis. The Ultra-High Performance Liquid Chromatography (U-HPLC) coupled to mass spectrometric detector revealed that Bacillus licheniformis can produce several molecules belonging to the surfactin and lichenysin families. Table 2 shows a list of these interesting molecules produced by strain GL174 that were further examined by fragmentation and mass spectrometry analysis, and issued characteristic and accurate $\mathrm{m} / \mathrm{z}$ values of precursors and more abundant fragments by Favaro et al. [26].

\section{Genome sequencing uncovers the genome structure and the presence of several genes involved in biocontrol and plant-bacteria interaction}

The genome of Bacillus licheniformis GL174 was sequenced using the IonProton platform, which produced a total of 18,010,684 reads. After filtering the sequences with a quality cutoff, the number of available reads dropped by $13,446,116$, for a total of $2,208,443,477$ sequenced bases.

Genome assembly was performed with the Newbler program, which yielded 441 contigs. Contigs whose length was lower than 200 bases were filtered, leaving a final dataset of 128 contigs that account for a genome length of 4,208,275 bases with a N50 of 77,942 bp and with an average GC content of $46.9 \%$.
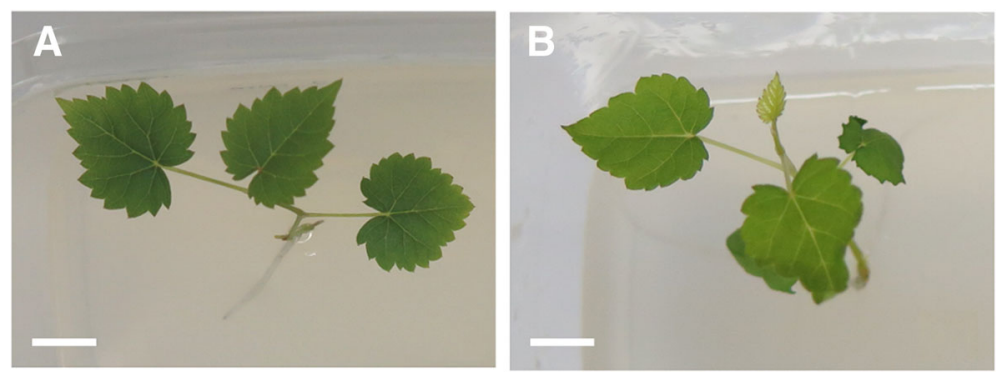

Fig. 1 Glera cutting 30 days after inoculation with GL174 (a) and control cutting (b). Bars: $2 \mathrm{~cm}$ 

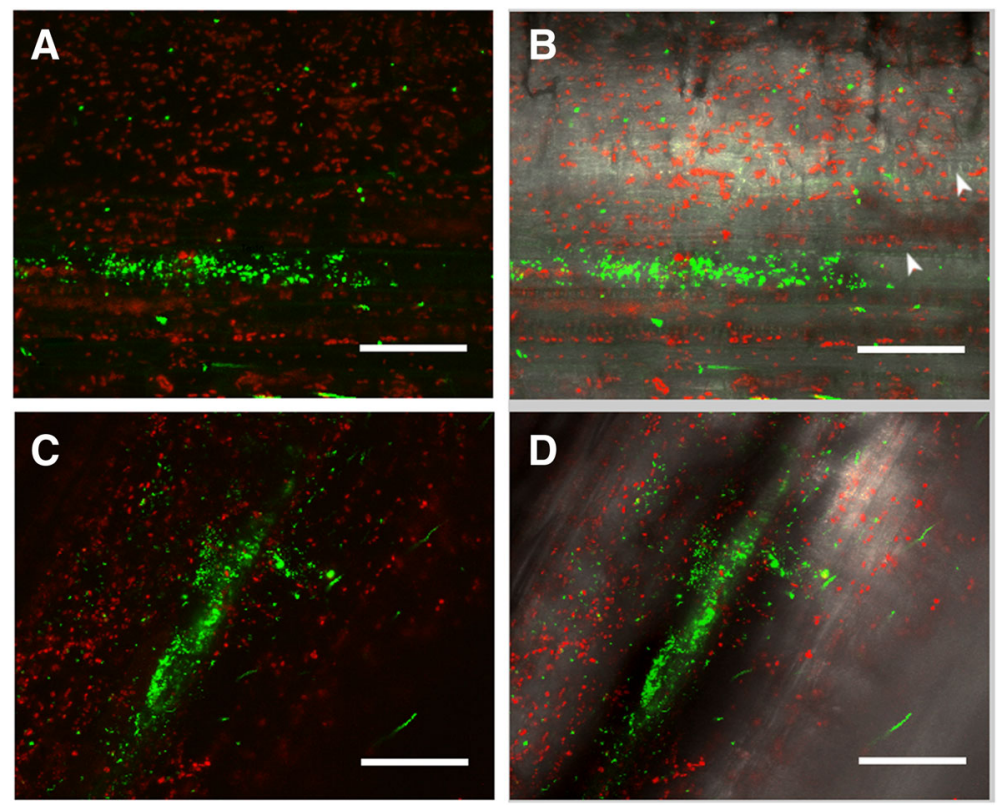

Fig. 2 LSCM of stem sections of Glera cuttings inoculated with Bacillus licheniformis GL174::gfp2x. Overlay of GFP signal (green) and chlorophyll (red) $(\mathbf{a}, \mathbf{c})$ and overlay of fluorescence and bright field $(\mathbf{b}, \mathbf{d})$. Stems samples $(\mathbf{a}, \mathbf{b}, \mathbf{c}, \mathbf{d})$ were observed 30 days after inoculation. Arrowheads indicate xylem vessels. Bars: $50 \mu \mathrm{m}$

The gene annotation process identified 3902 putative coding sequences (CDS) and 411 pseudogenes, representing a coding density of $87 \%$. Automatic gene annotation allowed us to assign a putative biological function to 2936 genes $(75 \%)$, while 966 genes $(25 \%)$ were annotated as "hypothetical protein". However, we discovered that almost all the CDSs with unassigned function (963) found a homologous gene in the non-redundant database. Using the annotation pipeline implemented in the BASys bacterial annotation system (https://www.basys.ca/), we assigned a COG functional class to $87 \%$ of the predicted genes. Amino acid metabolisms and transport (E), carbohydrate metabolism and transport (G) and transcription (K) were among the most abundant classes. All the COG categories found in GL174 were compared with the COG annotation of a reference genome of $\mathrm{Ba}$ cillus licheniformis DSM13 (GCA_000008425.1).

In line with the COG annotation and InterPro (https://www.ebi.ac.uk/interpro/) comparison among the predicted genes, many were involved in biocontrol and plant bacteria interaction (Table 3). The endophytic lifestyle of the strain is apparently helped by a set of gene-coding proteins associated with motility, chemotaxis and plant invasion. The strain has the genes encoding the machinery for flagella biosynthesis and chemotaxis. The genome annotation revealed genes che $A$, cheV, cheY, che $W$ and motA. In accordance with previous colonization analyses, genome examination showed several different gene codes for putative lytic enzymes favoring movement through the plant cell wall.
COG annotation revealed that many putative cell-wall-degrading enzymes are found within the GL174 genome, such as cellulases, endoglucanases, glucosidase and $\beta$-xylosidases. In addition to the last group of cell-wall-degrading enzymes, GL174 has many ABC-type transport system components (periplasmic components and permeases) for the movement of xylose and for its use as carbon source. The strain GL174 genome was found to contain $196 \mathrm{ABC}$-like transport system-related proteins, as well as 8 putative major facilitator transporters (MFT) and 38 putative phosphotransferase system family (PTS) genes. Among these groups of transport proteins, there were several transporters for phosphate, iron and nitrite/nitrate. We detected 16 gene codes for proteins related to siderophore biosynthesis and iron transport systems. In addition to these transport proteins, the strain also contains a set of putative proteins involved in phosphate metabolism, like alkaline phosphatase, inorganic pyrophosphatase/exopolyphosphatase, 3-phytase and some predicted phosphatases and pyrophosphatases. Gene annotation focused on nitrogen assimilation and metabolism demonstrated that the strain has genes encoding transporters for nitrate, nitrite and ammonium; it also contains nitrite and nitrate reductase that are involved in the nitrogen transformation processes. As potential biocontrol strain, we focused on the genes involved in the production of antimicrobial molecules and those which elicit induced resistance responses in the plant. COG analysis and UNiprot comparison revealed the three sub-units 

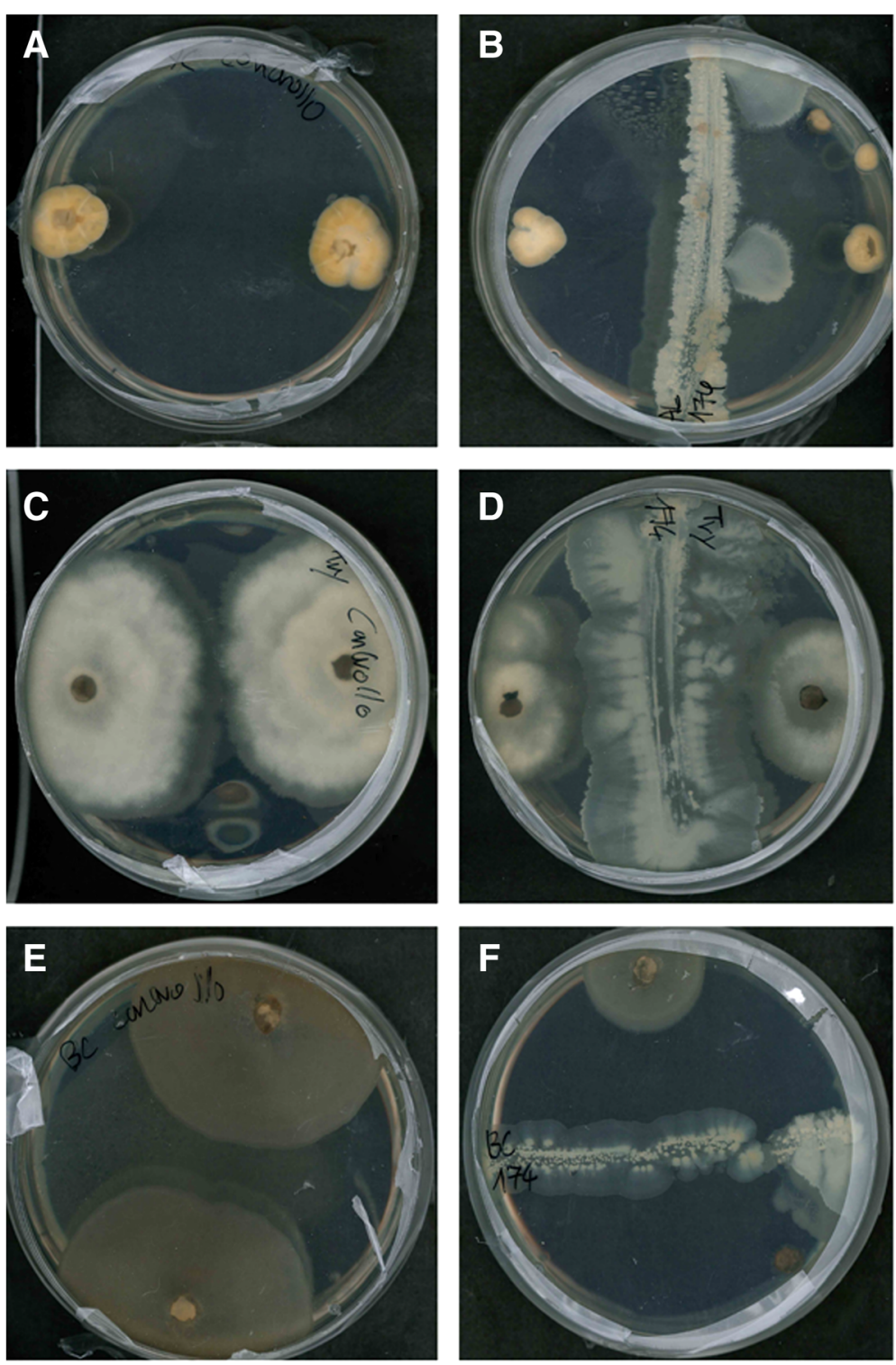

Fig. 3 In vitro effect of Bacillus licheniformis GL174 on the plant pathogens Phaeoacremonium aleophilum (a, b), Botryosphaeria spp (c, d), Botrytis cinerea $(\mathbf{e}, \mathbf{f})$. Reduction of mycelium growth due to bacterium action $(\mathbf{b}, \mathbf{d}, \mathbf{f})$ compared with negative controls without bacteria $(\mathbf{a}, \mathbf{c}, \mathbf{e})$

needed for biosynthesis of lipopeptides of the surfactin family, as well as other genes involved in non-ribosomal peptide synthesis. In addition to the putative genes involved in the biosynthesis of non-ribosomal peptides, other gene-encoding enzymes for antibiotic biosynthesis and transport were found. In fact, different sequences have been annotated as enzymes involved in the biosynthesis and transport of lichenicidin, a molecule belonging to the bacteriocin lantibiotics. Inside the genome of the B. licheniformis strain we also found some genes associated with the production of spermidine. Furthermore, the genome investigation has provided the sequences of putative genes involved in the biosynthesis of acetoin: the enzyme acetolactate synthase for the production of the acetoin precursor and the enzyme acetoin dehydrogenase that converts acetolactate into acetoin.

Table 1 Inhibition Index \pm \%SE of strain GL174 against some plant pathogens

\begin{tabular}{lccccc}
\hline & Botrytis cinerea & Phaeoacremonium aleophilum & Botryosphaeria spp. & Phytophthora infestans & Sclerotinia sclerotiorum \\
\hline Inhibition Index (\%) & $84.7 \pm 11$ & $86 \pm 7$ & $63 \pm 2$ & $16.3 \pm 3$ & $84.4 \pm 8$ \\
\hline
\end{tabular}


A Detached infiltrated leaves
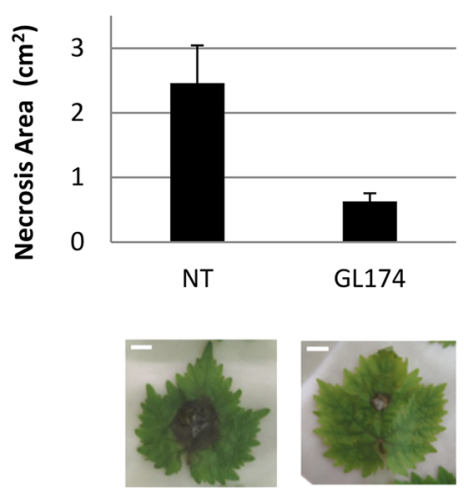

C In planta infiltrated leaves
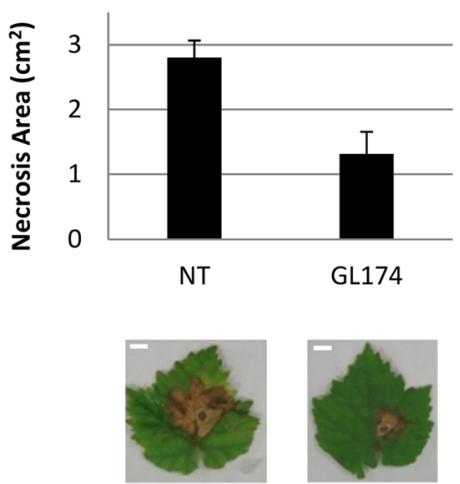

B Detached inoculated leaves

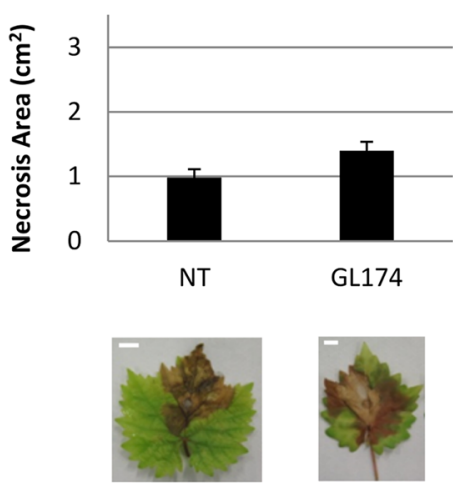

D In planta inoculated leaves

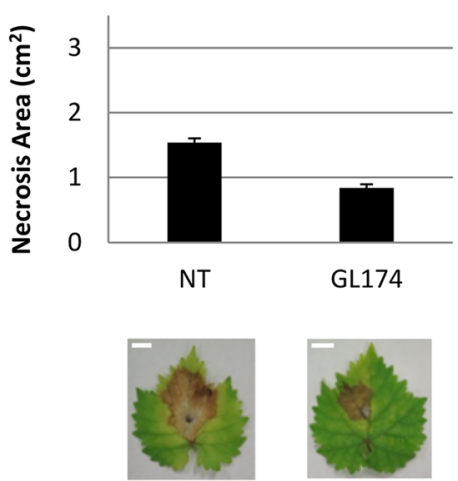

Fig. 4 In vivo effect of Bacillus licheniformis GL174 presence on grapevine Glera resistance against Botrytis cinerea. Symptom severity was determined on detached leaves $(\mathbf{a}, \mathbf{b})$ and on in planta leaves $(\mathbf{c}, \mathbf{d})$ in absence (NT) or in presence of bacteria (GL174). Except for (b) the plots report statistically significant differences between the treatments (t-student test, $P<0.05$ ). Data are reported $\pm S E M$. Example of leaves showing fungal lesions are reported for every set of samples. Bars: $2 \mathrm{~cm}$

Table 2 Lipopeptides produced by Bacillus licheniformis GL174, determined by LC-MS/MS. Nd: not determined

\begin{tabular}{ll}
\hline Lipopeptide & Aminoacidic sequence \\
\hline Linear surfactin & nd \\
Gyclic surfactin & Glu1Leu2Leu3Val4mAsp5Leu6Leu7 \\
& Glu1Leu2Leu3Val4Asp5Leu6Val7 \\
& Glu1Leu2Leu3Val4mAsp5Leu6Leu7 \\
Linear lichenysin & nd \\
Cyclic lichenysin & Gln1Leu2Leu3Val4mAsp5Leu6lle7 \\
& Gln1Leu2Leu3Val4mAsp5Leu6Val7 \\
& Gln1Leu2Leu3Val4Asp5Leu6Val7 \\
Gln1Leu2Leu3Val4AspLeu6lle7 \\
Gln1Leu2Leu3Val4mAsp5Leu6lle7 \\
\hline
\end{tabular}

Moreover, the enzyme responsible of the conversion of acetoin into 2,3-butanedione (acetoine reductase) was found by the UNiprot comparison. The genome analysis has also revealed the presence of two different sequences annotated as putative chitinases, enzymes able to degrade the fungal cell walls. Taking into account the ability of the bacterium to overcome plant response and colonize its tissues, we looked for gene-encoding enzymes for oxidative stress tolerance. We found five different coding sequences annotated as catalase and one sequence annotated as glutathione peroxidase.

\section{Discussion}

Many microorganisms are reported as biocontrol agents acting as pathogen antagonists in the soil or inside plants. The mechanisms underlying this effect are not completely clear. Biocontrol bacteria act directly against pathogens producing many types of antimicrobial compounds, and indirectly on the plant host eliciting its protective response. In the discovery process of new 
Table 3 Genes involved in the plant-bacteria relationship found in the Bacillus licheniformis GL174 genome

\begin{tabular}{|c|c|c|c|}
\hline Category & Protein name & Sequence ID & COG definition \\
\hline \multirow[t]{32}{*}{ Chemotaxis and motility } & $\begin{array}{l}\text { Probable methyl-accepting } \\
\text { chemotaxis protein BT9727_0469 }\end{array}$ & $\begin{array}{l}\text { TY90_12985 } \\
{[C]}\end{array}$ & $\begin{array}{l}\text { COG0840 Methyl-accepting } \\
\text { chemotaxis protein }\end{array}$ \\
\hline & Chemotaxis protein CheY & TY90_15200 & COG0784 FOG: CheY-like receiver \\
\hline & Flagellar motor switch phosphatase FliY & TY90_15195 & $\begin{array}{l}\text { COG1776 Chemotaxis protein } \\
\text { CheC, inhibitor of MCP methylation }\end{array}$ \\
\hline & Motility protein $B$ & TY90_17335 & COG1360 Flagellar motor protein \\
\hline & Methyl-accepting chemotaxis protein tlpC & TY90_17020 & $\begin{array}{l}\text { COG0840 Methyl-accepting } \\
\text { chemotaxis protein }\end{array}$ \\
\hline & Chemotaxis protein CheA & TY90_17615 & $\begin{array}{l}\text { COG0643 Chemotaxis protein } \\
\text { histidine kinase and related kinases }\end{array}$ \\
\hline & Methyl-accepting chemotaxis protein mcpA & TY90_06200 & $\begin{array}{l}\text { COG0840 Methyl-accepting } \\
\text { chemotaxis protein }\end{array}$ \\
\hline & Flagellar motor switch protein FliM & TY90_15190 & COG1868 Flagellar motor switch protein \\
\hline & $\begin{array}{l}\text { Probable methyl-accepting } \\
\text { chemotaxis protein BT9727_0469 }\end{array}$ & TY90_21790 & $\begin{array}{l}\text { COG5278 Predicted periplasmic } \\
\text { ligand-binding sensor domain }\end{array}$ \\
\hline & Motility protein $A$ & TY90_17330 & COG1291 Flagellar motor component \\
\hline & Swarming motility protein swrAA & TY90_02805 & na \\
\hline & Methyl-accepting chemotaxis protein $\mathrm{mcpC}$ & TY90_18510 & $\begin{array}{l}\text { COG0840 Methyl-accepting } \\
\text { chemotaxis protein }\end{array}$ \\
\hline & Swarming motility protein swrB & TY90_17590 & na \\
\hline & Methyl-accepting chemotaxis protein mcpA & TY90_06190 & $\begin{array}{l}\text { COG0840 Methyl-accepting } \\
\text { chemotaxis protein }\end{array}$ \\
\hline & Chemotaxis protein $\mathrm{CheV}$ & TY90_18185 & $\begin{array}{l}\text { COG0835 Chemotaxis signal } \\
\text { transduction protein }\end{array}$ \\
\hline & Methyl-accepting chemotaxis protein mсpB & TY90_00850 & $\begin{array}{l}\text { COG0840 Methyl-accepting } \\
\text { chemotaxis protein }\end{array}$ \\
\hline & Chemotaxis protein CheW & TY90_17610 & $\begin{array}{l}\text { COG0835 Chemotaxis signal } \\
\text { transduction protein }\end{array}$ \\
\hline & Chemotaxis protein methyltransferase & TY90_09925 & $\begin{array}{l}\text { COG1352 Methylase of chemotaxis } \\
\text { methyl-accepting proteins }\end{array}$ \\
\hline & $\begin{array}{l}\text { Chemotaxis response regulator } \\
\text { protein-glutamate methylesterase }\end{array}$ & TY90_17620 & $\begin{array}{l}\text { COG2201 Chemotaxis response } \\
\text { regulator containing a CheY-like } \\
\text { receiver domain and a } \\
\text { methylesterase domain }\end{array}$ \\
\hline & Flagellar motor switch protein FliG & TY90_15135 & $\begin{array}{l}\text { COG1536 Flagellar motor } \\
\text { switch protein }\end{array}$ \\
\hline & Methyl-accepting chemotaxis protein tlpA & TY90_21795 & $\begin{array}{l}\text { COG0840 Methyl-accepting } \\
\text { chemotaxis protein }\end{array}$ \\
\hline & Swarming motility protein swr $A B$ & TY90_02810 & $\begin{array}{l}\text { COG0265 Trypsin-like serine proteases, } \\
\text { typically periplasmic, contain } \\
\text { C-terminal PDZ domain }\end{array}$ \\
\hline & Flagellar assembly factor Fliw & TY90_02710 & function unknown \\
\hline & Flagellar motor switch phosphatase Fliy & TY90_15195 & $\begin{array}{l}\text { COG } 1776 \text { Chemotaxis protein } \\
\text { CheC, inhibitor of MCP methylation }\end{array}$ \\
\hline & Flagellar biosynthetic protein fliz & TY90_15205 & COG3190 Flagellar biogenesis protein \\
\hline & Flagellar biosynthetic protein fliR & TY90_15220 & $\begin{array}{l}\text { COG1684 Flagellar biosynthesis } \\
\text { pathway, component FliR }\end{array}$ \\
\hline & Probable flagellar assembly protein fliH & TY90_15140 & $\begin{array}{l}\text { COG1317 Flagellar biosynthesis/type } \\
\text { III secretory pathway protein }\end{array}$ \\
\hline & Flagellar biosynthetic protein flip & TY90_15210 & $\begin{array}{l}\text { COG1338 Flagellar biosynthesis } \\
\text { pathway, component FliP }\end{array}$ \\
\hline & Flagellar protein FliT & TY90_02740 & na \\
\hline & Flagellar FliJ protein & TY90_15150 & $\begin{array}{l}\text { COG2882 Flagellar } \\
\text { biosynthesis chaperone }\end{array}$ \\
\hline & Flagellar protein FliL & TY90_15185 & $\begin{array}{l}\text { COG1580 Flagellar basal } \\
\text { body-associated protein }\end{array}$ \\
\hline & Flagellar motor switch protein FliG & TY90_15135 & $\begin{array}{l}\text { COG1536 Flagellar motor } \\
\text { switch protein }\end{array}$ \\
\hline
\end{tabular}


Table 3 Genes involved in the plant-bacteria relationship found in the Bacillus licheniformis GL174 genome (Continued)

\begin{tabular}{|c|c|c|c|}
\hline Category & Protein name & Sequence ID & COG definition \\
\hline \multirow{3}{*}{ - } & Flagellar hook-basal body complex protein FliE & TY90_15125 & $\begin{array}{l}\text { COG1677 Flagellar hook-basal } \\
\text { body protein }\end{array}$ \\
\hline & Flagellar biosynthetic protein FliQ & TY90_15215 & $\begin{array}{l}\text { COG1987 Flagellar biosynthesis } \\
\text { pathway, component FliQ }\end{array}$ \\
\hline & Flagellar protein flis & TY90_02735 & COG1516 Flagellin-specific chaperone Flis \\
\hline \multirow{22}{*}{$\begin{array}{l}\text { Plant wall degrading } \\
\text { enzymes and } \\
\text { plant colonization }\end{array}$} & Putative aminopeptidase ysdC & TY90_10480 & COG1363 Cellulase M and related proteins \\
\hline & Putative aminopeptidase yhfE & TY90_04995 & COG1363 Cellulase M and related proteins \\
\hline & Putative aminopeptidase ytoP & TY90_07450 & COG1363 Cellulase $M$ and related proteins \\
\hline & Endoglucanase & TY90_03065 & COG2730 Endoglucanase \\
\hline & Endoglucanase B & TY90_17520 & COG2730 Endoglucanase \\
\hline & Reducing end xylose-releasing exo-oligoxylanase & $\begin{array}{l}\text { TY90_12415 } \\
{[C]}\end{array}$ & COG3405 Endoglucanase $Y$ \\
\hline & Beta-glucosidase & TY90_12740 & $\begin{array}{l}\text { COG1472 Beta-glucosidase-related } \\
\text { glycosidases }\end{array}$ \\
\hline & Trehalose-6-phosphate hydrolase & TY90_06865 & COG0366 Glycosidases \\
\hline & Uncharacterized lipoprotein ybbD & TY90_09030 & $\begin{array}{l}\text { COG1472 Beta-glucosidase-related } \\
\text { glycosidases }\end{array}$ \\
\hline & Oligo-1,6-glucosidase 1 & TY90_14210 & COG0366 Glycosidases \\
\hline & Intracellular maltogenic amylase & TY90_14180 & COG0366 Glycosidases \\
\hline & Pullulanase & TY90_07415 & $\begin{array}{l}\text { COG1523 Type II secretory pathway, } \\
\text { pullulanase PulA and related glycosidases }\end{array}$ \\
\hline & Alpha-amylase & TY90_16895 & COG0366 Glycosidases \\
\hline & Arabinan endo-1,5-alpha-L-arabinosidase & TY90_10485 & COG3507 Beta-xylosidase \\
\hline & Putative beta-xylosidase & $\begin{array}{l}\text { TY90_13465 } \\
{[C]}\end{array}$ & COG3507 Beta-xylosidase \\
\hline & Xylose isomerase & TY90_01590 & COG2115 Xylose isomerase \\
\hline & Multiple sugar-binding periplasmic receptor ChvE & TY90_13115 & $\begin{array}{l}\text { COG4213 ABC-type xylose } \\
\text { transport system, periplasmic component }\end{array}$ \\
\hline & Arabinan endo-1,5-alpha-L-arabinosidase & TY90_15525 & COG3507 Beta-xylosidase \\
\hline & Uncharacterized protein yxiA & TY90_08160 & COG3507 Beta-xylosidase \\
\hline & Ribose transport system permease protein rbsC & TY90_02405 & $\begin{array}{l}\text { COG1172 Ribose/xylose/arabinose/galactoside } \\
\text { ABC-type transport systems, } \\
\text { permease components }\end{array}$ \\
\hline & Xylose transport system permease protein $x y l H$ & TY90_13125 & $\begin{array}{l}\text { COG4214 ABC-type xylose transport } \\
\text { system, permease component }\end{array}$ \\
\hline & D-xylose-binding periplasmic protein & TY90_09370 & $\begin{array}{l}\text { COG4213 ABC-type xylose transport } \\
\text { system, periplasmic component }\end{array}$ \\
\hline \multirow[t]{10}{*}{$\begin{array}{l}\text { Iron nutrition } \\
\text { and metabolism }\end{array}$} & Rhizobactin siderophore biosynthesis protein rhbE & TY90_18465 & $\begin{array}{l}\text { COG3486 Lysine/ornithine } \\
\text { N-monooxygenase }\end{array}$ \\
\hline & Rhizobactin siderophore biosynthesis protein rhbD & TY90_18470 & $\begin{array}{l}\text { COG1670 Acetyltransferases, } \\
\text { including N-acetylases of } \\
\text { ribosomal proteins }\end{array}$ \\
\hline & Probable siderophore transport system permease protein yfiz & TY90_07875 & $\begin{array}{l}\text { COG0609 ABC-type Fe3 +-siderophore } \\
\text { transport system, permease component }\end{array}$ \\
\hline & Probable siderophore transport system permease protein yfhA & TY90_07870 & $\begin{array}{l}\text { COG0609 ABC-type Fe3 +-siderophore } \\
\text { transport system, permease component }\end{array}$ \\
\hline & Rhizobactin siderophore biosynthesis protein rhbC & TY90_18475 & na \\
\hline & Rhizobactin siderophore biosynthesis protein rhbF & TY90_18460 & na \\
\hline & Probable siderophore-binding lipoprotein yfiY & TY90_07880 & $\begin{array}{l}\text { COG0614 ABC-type Fe }+ \text { +-hydroxamate } \\
\text { transport system, periplasmic component }\end{array}$ \\
\hline & Probable siderophore-binding lipoprotein yfiY & TY90_08825 & $\begin{array}{l}\text { COG0614 ABC-type Fe } 3+- \text { hydroxamate } \\
\text { transport system, periplasmic component }\end{array}$ \\
\hline & Ferrous iron transport protein $B$ & TY90_15330 & COG0370 Fe2+ transport system protein B \\
\hline & Iron(3+)-hydroxamate import system permease protein fhuG & TY90_12850 & $\begin{array}{l}\text { COG0609 ABC-type Fe3 +-siderophore } \\
\text { transport system, permease component }\end{array}$ \\
\hline
\end{tabular}


Table 3 Genes involved in the plant-bacteria relationship found in the Bacillus licheniformis GL174 genome (Continued)

\begin{tabular}{|c|c|c|c|}
\hline Category & Protein name & Sequence ID & COG definition \\
\hline \multirow{6}{*}{-} & Iron-uptake system permease protein feuC & TY90_02125 & $\begin{array}{l}\text { COG0609 ABC-type Fe3 +-siderophore } \\
\text { transport system, permease component }\end{array}$ \\
\hline & Iron(3+)-hydroxamate-binding protein yxeB & TY90_11500 & $\begin{array}{l}\text { COG0614 ABC-type Fe3 +--hydroxamate } \\
\text { transport system, periplasmic component }\end{array}$ \\
\hline & Iron(3+)-hydroxamate import ATP-binding protein FhuC & TY90_12855 & $\begin{array}{l}\text { COG1120 ABC-type cobalamin/Fe3 +-siderophores } \\
\text { transport systems, ATPase components }\end{array}$ \\
\hline & Iron(3+)-hydroxamate-binding protein yxeB & TY90_15350 & $\begin{array}{l}\text { COG0614 ABC-type Fe3 +-hydroxamate } \\
\text { transport system, periplasmic component }\end{array}$ \\
\hline & Iron(3+)-hydroxamate-binding protein fhuD & TY90_13845 & $\begin{array}{l}\text { COG0614 ABC-type Fe3 +-hydroxamate } \\
\text { transport system, periplasmic component }\end{array}$ \\
\hline & Iron-uptake system-binding protein & TY90_02115 & $\begin{array}{l}\text { COG0614 ABC-type Fe3 + -hydroxamate } \\
\text { transport system, periplasmic component }\end{array}$ \\
\hline \multirow[t]{19}{*}{$\begin{array}{l}\text { Phosphate nutrition } \\
\text { and metabolism }\end{array}$} & Phosphate-binding protein pstS & TY90_12210 & $\begin{array}{l}\text { COG0226 ABC-type phosphate transport } \\
\text { system, periplasmic component }\end{array}$ \\
\hline & Phosphate import ATP-binding protein PstB 1 & TY90_12230 & $\begin{array}{l}\text { COG1117 ABC-type phosphate } \\
\text { transport system, ATPase component }\end{array}$ \\
\hline & Sulfate permease CysP & TY90_14565 & COG0306 Phosphate/sulphate permeases \\
\hline & Probable low-affinity inorganic phosphate transporter & TY90_10295 & COG0306 Phosphate/sulphate permeases \\
\hline & Probable $A B C$ transporter permease protein yqgl & TY90_12220 & $\begin{array}{l}\text { COG0581 ABC-type phosphate transport } \\
\text { system, permease component }\end{array}$ \\
\hline & Phosphate import ATP-binding protein PstB 2 & TY90_12225 & $\begin{array}{l}\text { COG1117 ABC-type phosphate transport } \\
\text { system, ATPase component }\end{array}$ \\
\hline & Probable $A B C$ transporter permease protein yqgH & TY90_12215 & $\begin{array}{l}\text { COG0573 ABC-type phosphate transport } \\
\text { system, permease component }\end{array}$ \\
\hline & Uncharacterized protein yqeW & TY90_11930 & COG1283 Na+/phosphate symporter \\
\hline & UPF0111 protein ykaA & TY90_10290 & $\begin{array}{l}\text { COG1392 Phosphate transport } \\
\text { regulator (distant homolog of PhoU) }\end{array}$ \\
\hline & Alkaline phosphatase 3 & TY90_20965 & COG1785 Alkaline phosphatase \\
\hline & Probable manganese-dependent inorganic pyrophosphatase & TY90_02230 & $\begin{array}{l}\text { COG1227 Inorganic pyrophosphatase/ } \\
\text { exopolyphosphatase }\end{array}$ \\
\hline & Uncharacterized protein ypjD & TY90_17920 & COG1694 Predicted pyrophosphatase \\
\hline & MazG Nucleotide Pyrophosphohydrolase & TY90_20180 & COG1694 Predicted pyrophosphatase \\
\hline & Bifunctional oligoribonuclease and PAP phosphatase nrnA & TY90_16540 & $\begin{array}{l}\text { COG0618 Exopolyphosphatase- } \\
\text { related proteins }\end{array}$ \\
\hline & Uncharacterized protein YhcW & TY90_11780 & $\begin{array}{l}\text { COG0637 Predicted phosphatase/ } \\
\text { phosphohexomutase }\end{array}$ \\
\hline & Putative beta-phosphoglucomutase & TY90_14215 & $\begin{array}{l}\text { COG0637 Predicted phosphatase/ } \\
\text { phosphohexomutase }\end{array}$ \\
\hline & Uncharacterized protein yvdC & TY90_08560 & COG1694 Predicted pyrophosphatase \\
\hline & Pyrophosphatase ppaX & TY90_02900 & COG0546 Predicted phosphatases \\
\hline & 3-phytase & TY90_13145 & na \\
\hline \multirow[t]{10}{*}{$\begin{array}{l}\text { Nitrogen uptake } \\
\text { and metabolism }\end{array}$} & NifU-like protein & TY90_07755 & $\begin{array}{l}\text { COG0822 NifU homolog involved } \\
\text { in Fe-S cluster formation }\end{array}$ \\
\hline & Putative ammonium transporter sll0108 & $\begin{array}{l}\text { TY90_15930 } \\
{[C]}\end{array}$ & COG0004 Ammonia permease \\
\hline & Assimilatory nitrate reductase electron transfer subunit & TY90_04420 & COG1251 NAD(P)H-nitrite reductase \\
\hline & Nitrite reductase $[\mathrm{NAD}(\mathrm{P}) \mathrm{H}]$ & TY90_04410 & COG1251 NAD(P)H-nitrite reductase \\
\hline & Nitrate transporter & TY90_20435 & COG2223 Nitrate/nitrite transporter \\
\hline & Assimilatory nitrite reductase $[\mathrm{NAD}(\mathrm{P}) \mathrm{H}]$ small subunit & TY90_04405 & $\begin{array}{l}\text { COG2146 Ferredoxin subunits of } \\
\text { nitrite reductase and ring-hydroxylating } \\
\text { dioxygenases }\end{array}$ \\
\hline & Uncharacterized transporter ywcJ & TY90_01155 & COG2116 Formate/nitrite family of transporters \\
\hline & Uncharacterized transporter yrhG & TY90_11795 & COG2116 Formate/nitrite family of transporters \\
\hline & Nitrate reductase beta chain & TY90_03135 & COG1140 Nitrate reductase beta subunit \\
\hline & Nitrate reductase gamma chain & TY90_03145 & COG2181 Nitrate reductase gamma subunit \\
\hline
\end{tabular}


Table 3 Genes involved in the plant-bacteria relationship found in the Bacillus licheniformis GL174 genome (Continued)

\begin{tabular}{|c|c|c|c|}
\hline Category & Protein name & Sequence ID & COG definition \\
\hline \multirow{7}{*}{ - } & $\begin{array}{l}\text { Probable nitrate reductase molybdenum cofactor assembly chaperone } \\
\text { NarJ }\end{array}$ & TY90_03140 & COG2180 Nitrate reductase delta subunit \\
\hline & Uncharacterized $A B C$ transporter permease protein ytID & TY90_07125 & $\begin{array}{l}\text { COG0600 ABC-type nitrate/sulfonate/ } \\
\text { bicarbonate transport system, } \\
\text { permease component }\end{array}$ \\
\hline & Nitrate transporter & TY90_20435 & COG2223 Nitrate/nitrite transporter \\
\hline & Putative aliphatic sulfonates transport permease protein ssuC & TY90_11560 & $\begin{array}{l}\text { COG0600 ABC-type nitrate/sulfonate/ } \\
\text { bicarbonate transport system, } \\
\text { permease component }\end{array}$ \\
\hline & Aliphatic sulfonates import ATP-binding protein SsuB & TY90_11550 & $\begin{array}{l}\text { COG1116 ABC-type nitrate/sulfonate/ } \\
\text { bicarbonate transport system, } \\
\text { ATPase component }\end{array}$ \\
\hline & Uncharacterized ABC transporter ATP-binding protein YtIC & TY90_07130 & $\begin{array}{l}\text { COG1116 ABC-type nitrate/sulfonate/ } \\
\text { bicarbonate transport system, } \\
\text { ATPase component }\end{array}$ \\
\hline & Putative aliphatic sulfonates-binding protein & TY90_1155 & $\begin{array}{l}\text { COG0715 ABC-type nitrate/sulfonate/ } \\
\text { bicarbonate transport systems, } \\
\text { periplasmic components }\end{array}$ \\
\hline \multirow{20}{*}{$\begin{array}{l}\text { Antibiotics and } \\
\text { secondary metabolites } \\
\text { production and } \\
\text { transport, } \\
\text { biocontrol-related genes }\end{array}$} & Surfactin synthase thioesterase subunit & TY90_12925 & $\begin{array}{l}\text { COG3208 Predicted thioesterase } \\
\text { involved in non-ribosomal } \\
\text { peptide biosynthesis }\end{array}$ \\
\hline & Surfactin synthase subunit 2 & TY90_21750 & $\begin{array}{l}\text { COG1020 Non-ribosomal peptide } \\
\text { synthetase modules } \\
\text { and related proteins }\end{array}$ \\
\hline & Putative phosphoenolpyruvate synthase & TY90_00915 & $\begin{array}{l}\text { COG3319 Thioesterase domains } \\
\text { of type I polyketide synthases } \\
\text { or non-ribosomal peptide synthetases }\end{array}$ \\
\hline & Surfactin synthase subunit 2 & TY90_21285 & $\begin{array}{l}\text { COG1020 Non-ribosomal peptide } \\
\text { synthetase modules and } \\
\text { related proteins }\end{array}$ \\
\hline & D-alanine--poly(phosphoribitol) ligase subunit 1 & TY90_01430 & $\begin{array}{l}\text { COG1020 Non-ribosomal peptide } \\
\text { synthetase modules } \\
\text { and related proteins }\end{array}$ \\
\hline & Putative phosphoenolpyruvate synthase & TY90_16790 & $\begin{array}{l}\text { COG3319 Thioesterase } \\
\text { domains of type I polyketide } \\
\text { synthases or non-ribosomal } \\
\text { peptide synthetases }\end{array}$ \\
\hline & Surfactin synthase subunit 1 & TY90_17065 & $\begin{array}{l}\text { COG1020 Non-ribosomal } \\
\text { peptide synthetase modules } \\
\text { and related proteins }\end{array}$ \\
\hline & Surfactin synthase subunit 3 & TY90_12920 & $\begin{array}{l}\text { COG1020 Non-ribosomal } \\
\text { peptide synthetase modules } \\
\text { and related proteins }\end{array}$ \\
\hline & Putative phosphoenolpyruvate synthase & TY90_00550 & $\begin{array}{l}\text { COG3319 Thioesterase } \\
\text { domains of type I polyketide } \\
\text { synthases or non-ribosomal } \\
\text { peptide synthetases }\end{array}$ \\
\hline & lantibiotic ABC transporter ATP-binding protein & TY90_19070 & $\begin{array}{l}\text { COG1131 ABC-type multidrug } \\
\text { transport system, ATPase component }\end{array}$ \\
\hline & lantibiotic ABC transporter ATP-binding protein & TY90_19920 & $\begin{array}{l}\text { COG1131 ABC-type multidrug } \\
\text { transport system, ATPase component }\end{array}$ \\
\hline & lantibiotic immunity protein & TY90_01250 & na \\
\hline & lantibiotic immunity protein & TY90_01260 & na \\
\hline & lantibiotic lichenicidin A1 & TY90_01200 & na \\
\hline & lantibiotic lichenicidin A2 & TY90_01205 & na \\
\hline & lantibiotic-modifying protein & TY90_01195 & na \\
\hline & lantibiotic-modifying protein & TY90_01210 & na \\
\hline & $\operatorname{LanY}$ & TY90_01235 & na \\
\hline & bacteriocin biosynthesis protein SagD & TY90_04705 & $\begin{array}{l}\text { COG1944 Uncharacterized } \\
\text { conserved protein }\end{array}$ \\
\hline & bacteriocin maturation protein & TY90_04710 & na \\
\hline
\end{tabular}


Table 3 Genes involved in the plant-bacteria relationship found in the Bacillus licheniformis GL174 genome (Continued)

\begin{tabular}{|c|c|c|c|}
\hline Category & Protein name & Sequence ID & COG definition \\
\hline \multirow{14}{*}{ - } & chitinase & TY90_20245 & $\begin{array}{l}\text { COG3979 Uncharacterized protein } \\
\text { contain chitin-binding domain type } 3\end{array}$ \\
\hline & chitinase & TY90_20250 & COG3325 Chitinase \\
\hline & $\begin{array}{l}\text { Spermidine/putrescine transport } \\
\text { system permease protein PotC }\end{array}$ & TY90_17055 & $\begin{array}{l}\text { COG1 } 177 \text { ABC-type spermidine/ } \\
\text { putrescine transport system, } \\
\text { permease component II }\end{array}$ \\
\hline & $\begin{array}{l}\text { Spermidine/putrescine import } \\
\text { ATP-binding protein PotA }\end{array}$ & TY90_17045 & $\begin{array}{l}\text { COG3839 ABC-type sugar } \\
\text { transport systems, ATPase components }\end{array}$ \\
\hline & $\begin{array}{l}\text { Spermidine/putrescine-binding } \\
\text { periplasmic protein } 2\end{array}$ & TY90_17040 & $\begin{array}{l}\text { COG0687 Spermidine/putrescine-binding } \\
\text { periplasmic protein }\end{array}$ \\
\hline & Spermidine synthase & TY90_01960 & COG0421 Spermidine synthase \\
\hline & acetoin dehydrogenase & TY90_13415 & $\begin{array}{l}\text { COG3284 Transcriptional activator } \\
\text { lof acetoin/glycerol metabolism }\end{array}$ \\
\hline & acetoin dehydrogenase & TY90_20060 & na \\
\hline & acetoin reductase & TY90_03165 & $\begin{array}{l}\text { COG1028 Dehydrogenases with } \\
\text { different specificities (related to } \\
\text { short-chain alcohol dehydrogenases) }\end{array}$ \\
\hline & acetoin utilization protein $\mathrm{AcuB}$ & TY90_20055 & COG0517 FOG: CBS domain \\
\hline & $\begin{array}{l}\text { acetoin:2,2 C6-dichlorophenolindophenol } \\
\text { oxidoreductase subunit alpha }\end{array}$ & TY90_13395 & $\begin{array}{l}\text { COG1071 Pyruvate/2-oxoglutarate } \\
\text { dehydrogenase complex, dehydrogenase } \\
\text { (E1) component, eukaryotic } \\
\text { type, alpha subunit }\end{array}$ \\
\hline & acetolactate synthase & TY90_02385 & $\begin{array}{l}\text { COG0028 Thiamine pyrophosphate-requiring } \\
\text { enzymes [acetolactate synthase, } \\
\text { pyruvate dehydrogenase (cytochrome), } \\
\text { glyoxylate carboligase, } \\
\text { phosphonopyruvate decarboxylase] }\end{array}$ \\
\hline & acetolactate synthase & TY90_05725 & $\begin{array}{l}\text { COG0440 Acetolactate synthase, } \\
\text { small (regulatory) subunit }\end{array}$ \\
\hline & acetolactate synthase catalytic subunit & TY90_05730 & $\begin{array}{l}\text { COG0440 Acetolactate synthase, } \\
\text { small (regulatory) subunit }\end{array}$ \\
\hline \multirow{3}{*}{$\begin{array}{l}\text { Oxidative } \\
\text { stress response }\end{array}$} & Catalase X & TY90_01280 & COG0753 Catalase \\
\hline & Probable manganese catalase & TY90_03405 & COG3546 Mn-containing catalase \\
\hline & Glutathione peroxidase homolog BsaA & TY90_00120 & COG0386 Glutathione peroxidase \\
\hline
\end{tabular}

bioactive strains, we focused on bacterial endophytes for their ability to spread along plants and colonize their inner tissues contrasting pathogens directly inside them.

In this work, we analyzed some traits of Bacillus licheniformis GL174 to assess its potential biocontrol activity. This bacterium, isolated from surface-sterilized leaves of Vitis vinifera cv. Glera, sampled in the Prosecco wine-making area, has been recognized as a Bacillus licheniformis strain [19]. Bacteria of the genus Bacillus are very common endophytes of a great variety of plant species [27, 28]. We then demonstrated that Bacillus licheniformis GL174 is a Glera endophyte - we assessed its ability to colonize Glera cuttings by using a GFP-tagged strain, following Koch's postulate in the discovery of new endophytes. To this end, the ability of $\mathrm{Ba}$ cillus licheniformis GL174 to colonize and inhabit stem tissues of Glera cuttings was evaluated 30 days post-inoculation. Successful visualization of B. licheniformis GL174 in the inner tissues showed that this strain is a true bacterial endophyte of Vitis vinifera cultivar Glera. According to Compant et al. [4], the colonization is not homogenous: bacteria are more often located in roots and stems rather than in leaves and reproductive structures where they tend to be more diluted. To check if $B$. licheniformis GL174 could be used as an endophytic biocontrol agent, we focused on its biochemical activities and genomic characteristics. Many endophytes can reduce infection by bacterial and fungal pathogens $[5,8,12]$. To potentially use this strain in grapevine cultivation, we checked if B. licheniformis GL174 could act against some fungal pathogens that severely damage vineyards in the Glera cultivation area. We tested in vitro the effect of the endophyte co-culturing $\mathrm{Ba}$ cillus licheniformis GL174 and the specific grapevine fungal pathogens Phaeoacremonium aleophilum, Botryosphaeria spp. that are involved in the "esca" disease and other trunk diseases of grapevine plants [29, 30], like Botrytis cinerea, which causes gray mold on grape, and against two general pathogens Phytophthora infestans and Sclerotinia sclerotiorum. In vitro tests demonstrated that the analyzed strain caused great mycelium growth reduction in Botrytis cinerea, Phaeoacremonium aleophilum and Sclerotinia sclerotiorum. Minor reduction was recorded in Phytophtora infestans. The inhibition percentages found in this work are 
comparable with other reduction effects reported for Bacillus subtilis and Bacillus amyloliquefaciens [31, 32]. To confirm this antifungal trait the strain was used in an in vivo test involving grapevine plants and the fungal pathogen $\mathrm{Bo}$ trytis cinerea. The first part of the experiment, on the detached leaves, has demonstrated that the strain is effective against the pathogen when the leaves were infiltrated directly with the bacteria suspension. The antifungal effect of the bacteria could be due to nutritional competition and to the bacterial production of some diffusible molecules that can avoid or reduce pathogen growth [33]. Detached leaves from plants inoculated when cuttings (2 months before fungal infection) did not show any sign of protection. On the contrary, in the in planta experiment, both bacterial inoculation ways resulted effective for the plant protection. This indicates that the protective effect will probably be exerted by systemically induced defenses (i.e. by ISR), via activation of specific synthetic pathways that produce metabolites transferred through transport tissue protecting the plant from the gray mold. Detached infected leaves do not maintain the connection with the plant and thus leaves are not protected by the plant ISR, once infected by Botrytis. Bacillus licheniformis is reported in the literature as a producer of some lipopeptides [34] and chitinase [35], both of which may act as antifungal agents. The production of these molecules by Bacillus licheniformis GL174 was confirmed by tandem mass spectrometry. Spectra analysis showed that the endophyte constitutively produces many LP homologues of the lichenysin (5 compounds, Table 2) and surfactin (4 compounds, Table 2) families. Within each family there are many homologues that differ in chemical structure: linear and cyclic molecules, different acylic chain length, in amino acid in position 7, and/or methylation of some amino acid residues. Using these experimental conditions, no mycosubtilin production was detected when analyzing this strain. These results confirm that Bacillus licheniformis is a LP producer, as also demonstrated for a B. licheniformis strain isolated from marine sediments [36]. Moreover, this strain could be double effective for plant protection: in addition to the antimicrobial effects, molecules of the surfactin family are effectively recognized by plants eliciting an induced plant systemic response (ISR) that leads to increased pathogen tolerance [37-39]. Surfactins and lichenysins also have strong biosurfactant action, and help bacteria colonize and form biofilms as well as improve cell movements. On the other hand, this effect indirectly impairs colonization by other microorganisms such as pathogens [40]. Considering the results of the biochemical assays, we sequenced the whole strain genome, obtaining a large dataset of sequences to support previous results and provide further information about GL174 abilities. When analyzing coding sequence annotation, we identified a set of genes that complement the biochemical findings with genomic evidence, demonstrating the presence of some genes involved in plant-bacteria interaction and in plant pathogen biocontrol.

In analyzing the relationships between plant hosts and bacteria, we first evaluated the presence of genes involved in motility and chemotaxis, as recently suggested by Hardoim et al. [5]. The expression of these genes could lead to efficient plant colonization by bacteria. Moreover, with regard to plant colonization, we demonstrated the presence of cell-wall lytic enzymes. These enzymes can loosen the cell wall and help bacteria enter the apoplastic space: this bacterial ability could help efficient colonization by the GL174 strain and consequently exert its biocontrol activity directly from the inner tissues of plants $[5,41]$. The presence of many genes for siderophore production and transport is another ability that can contribute to the biocontrolling effect of the strain. Indeed, these genes suggest that strain GL174 could efficiently compete with other microorganisms for iron nutrition, controlling the number of possible pathogens in the plant as shown for other PGP strains [41, 42]. Even though not strictly related to pathogen biocontrol, the ability to mobilize poorly bioavailable phosphate is also a remarkable feature of the strain. The presence of the 3-phytase gene suggests that strains like this could be used as biofertilizers in organic phosphate-rich soil [43]. In accordance with the mass spectrometry analysis of the lipopeptides, we identified the coding sequences of the three sub-units of the mega-enzyme responsible for the biosynthesis of the surfactin family lipopeptides-surfactin synthetase. This showed that the strain has genes to produce lipopeptides and that its set is expressed even in in vitro condition. Genome sequences were recognized by the COG analysis and UNiprot comparison as encoding proteins involved in the production and mobilization of bacteriocins. On the contrary to lipopeptides, these molecules are ribosomally-synthesized antibiotics, with a great structural diversity [44]. The analysis revealed the presence of putative enzymes for the class of lantibiotics (biosynthesis, modification and transport, see Table 3). All these genes, in addition to the gene encoding a chitinase, provide the bacterium a set of molecular weapons for biocontrol of pathogens. The presence of such different mechanisms of action against other microrganisms could be an effective strategy of antagonism affecting the development of efficient resistance strategies in the target organisms. The biocontrol effect of the strain could be exerted by the induction in the host plant of a systemic resistance response [5]. The genome analysis has revealed that the strain has the genes for production and transport of acetoin and 2,3-butanediol. Both these volatile compounds have been recognized as elicitors of plant resistance $[45,46]$. Interestingly, 2,3-butanediol is also able to promote plant defence and biomass growth [47]. The presence in the genome of the spermidine synthase is another biocontrol-related trait of the strain. In 
fact, spermidine has biocontrol effects due to its action against biofilm formation. Moreover, this polyamine influences plant-bacteria interaction: it is recognized by plants and it can promote plant growth-modulating cell expansion and modulate hormonal balance [48]. In endophyte colonization, the bacterial expression of oxidative stress-related genes seems important to cope with the oxygen-reactive species that plants produce in their tissues [5]. The genome of strain GL174 contains different coding sequences for enzymes devoted to scavenging the oxidative burst, such as five different catalases and one glutathione peroxidase. These enzymes could enable bacteria to live inside plant tissues without being damaged by the oxidative burst of the plant. All these genomic data suggest that the strain can potentially be employed as a biocontrol agent. As the strain is a natural endophyte of Glera, it may proficiently and safely be used on grapevine in the field. This was confirmed by the results we obtained inoculating Glera cuttings, which were completely healthy and well colonized 30 days post-bacterization. The strain is also non-pathogenic for Arabidopsis thaliana, as previously demonstrated [20].

\section{Conclusions}

The results of this integrated approach suggest that $B a$ cillus licheniformis GL174 could act in Vitis vinifera Glera as a biocontrol agent, given its ability to inhibit fungal pathogen growth and to reduce the severity of fungal infection in vitro. This study is part of a project that aims to investigate the microbial biodiversity in the Veneto Glera vineyards to develop new agricultural practices and products for environmentally-friendly grapevine cultivation. Bacillus licheniformis GL174 is a good candidate to be tested in open field conditions to verify biocontrol effects on Vitis vinifera cv. Glera as well as other economically important crops.

\section{Additional file}

Additional file 1: Dual plate assay. In vitro effect of Bacillus licheniformis GL174 on the plant pathogens Phytophtora infestans (A, B), and Sclerotinia sclerotiorum ( $C, D)$. Reduction of mycelium growth due to bacterium action $(B, D)$ compared with negative controls without bacteria ( $A, C$ ). (TIFF $1906 \mathrm{~kb}$ )

\footnotetext{
Abbreviations

CDS: Coding sequence; COG: Cluster of orthologs; ESI-MS: Electrospray ionization mass spectrometry; GFP: Green fluorescent protein; ISR: Induced systemic resistance; LP: Lipopeptide; LSCM: Laser Scanning Confocal Microscopy; MFT: Major facilitator transporter; MS: Murashige and Skoog; NA: Nutrient Agar; NB: Nutrient broth; PGP: Plant growth promoting; PTS: Phosphotransferase System Familiy; U-HPLC: Ultra-High Performance Liquid Chromatography
}

\section{Funding}

This work was funded by the Misura 124 Project ENDOFLORVIT (Reg. CE 1698/2005, DGR "Regione del Veneto" n. 1604 del 31/07/2012, request 2307732) and by "Progetto di Ricerca di Ateneo 2013- CPDA139795". The funding agencies had not any role in the design of the study, collection, analysis, and interpretation of data and in writing the manuscript.

\section{Availability of data and materials}

The dataset generated and or analysed during the current study are available in the BioProject database with accession number PRJNA274883, https://www.ncbi.nlm.nih.gov/bioproject/?term=PRJNA274883

\section{Authors' contributions}

$\mathrm{SN}$ performed the research and co-wrote the manuscript. FZ and MZ helped to perform the in vivo antagonism assays. ALT and ELB performed confocal microscopy analyses. VG and EB carried out in vitro dual antagonism assays. NB, AT and GV carried out the genome sequencing and assembling. NV and NB performed the genome annotation and helped in data analysis. SM maintained the bacterial and plant cultures. GF performed the mass spectrometry analysis. MZ and AS co-designed and co-supervised the research and participated in manuscript writing. BB conceived, performed, supervised the research and co-wrote the article.

All the authors read and approved the final manuscript.

Ethics approval and consent to participate

Not applicable

\section{Consent for publication}

Not applicable

\section{Competing interests}

The authors declare that they have no competing interests.

\section{Publisher's Note}

Springer Nature remains neutral with regard to jurisdictional claims in published maps and institutional affiliations.

\section{Author details}

'Botanical Garden and Department of Biology, University of Padova, Padova, Italy. ${ }^{2}$ Department of Biology, University of Padova, Padova, Italy. ${ }^{3}$ Department of Biotechnology, University of Verona, Verona, Italy. ${ }^{4}$ Department of Chemical Sciences, University of Padova, Padova, Italy. ${ }^{5} \mathrm{CRIBI}$ Biotechnology Center, Padova, Italy. ${ }^{6}$ DAFNAE Department of Agronomy Food Natural Resources Animals and Environment, Legnaro, PD, Italy.

Received: 6 March 2018 Accepted: 7 October 2018

Published online: 16 October 2018

\section{References}

1. Ciancio A, Pieterse CM, Mercado-Blanco J. Editorial: Harnessing useful rhizosphere microorganisms for pathogen and pest biocontrol. Front Microbiol. 2016;7:1620

2. Gaiero JR, McCall C, Thompson K, Day NJ, Best AS, Dunfield KE. Inside the root microbiome: bacterial root endophytes and plant growth promotion. Am J Bot. 2013;100(9):1738-50.

3. Hardoim PR, van Overbeek LS, Elsas JD. Properties of bacterial endophytes and their proposed role in plant growth. Trends Microbiol. 2008;16(10):463-71.

4. Compant S, Mitter B, Colli-Mull JG, Gangl H, Sessitsch A. Endophytes of grapevine flowers, berries, and seeds: identification of cultivable bacteria, comparison with other plant parts, and visualization of niches of colonization. Microb Ecol. 2011;62(1):188-97.

5. Hardoim PR, van Overbeek LS, Berg G, Pirttilä AM, Compant S, Campisano A, et al. The hidden world within plants: ecological and evolutionary considerations for defining functioning of microbial endophytes. Microbiol Mol Biol Rev. 2015:79(3):293-320.

6. Ryan RP, Germaine K, Franks A, Rayan DJ, Dowling DN. Bacterial endophytes: recent developments and applications. FEMS Microbiol Lett. 2008;278:1-9.

7. Verhagen BWM, Trotel-Aziz P, Jeandet P, Baillieul F, Aziz A. Improved resistance against Botrytis cinerea by grapevine-associated bacteria that 
induce a prime oxidative burst and phytoalexin production. Phytopathology. 2011;101:768-77.

8. Pèrez-Garcìa A, Romero D, de Vincente A. Plant protection and growth stimulation by microorganisms biotechnological applications of bacilli in agriculture. Curr Opin Biotech. 2011;22:187-93.

9. Ongena M, Jourdan E, Adam A, Paquot M, Brans A, Joris B, Thonart P. Surfactin and fengycin lipopeptides of Bacillus subtilis as elicitors of induced systemic resistance in plants. Environmen Microbiol. 2007;9(4):1084-90.

10. Bulgarelli D, Rott M, Schlaeppi K, Ver Loren van Themaat E, Ahmadinejad N, Assenza F, Schulze-Lefert P. Revealing structure and assembly cues for Arabidopsis root-inhabiting bacterial microbiota. Nature. 2012;488:91-5.

11. Germaine K, Keogh E, Garcia-Cabellos G, Borremans B, Lelie D, Barac T, Dowling DN. Colonisation of poplar trees by gfp expressing bacterial endophytes. FEMS Microbiol Ecol. 2004;48(1):109-18.

12. Compant S, Kaplan H, Sessitsch A, Nowak J, Barka EA, Clément C. Endophytic colonization of Vitis vinifera L. by Burkholderia phytofirmans strain PsJN: from the rhizosphere to inflorescence tissues. FEMS Microbiol Ecol. 2008;63(1):84-93.

13. Singh MK, Kushwaha C, Singh RK. Studies on endophytic colonization ability of two upland rice endophytes, Rhizobium sp. and Burkholderia sp., using green fluorescent protein reporter. Curr Microbiol. 2009;59(3):240-3.

14. Larrainzar E, O'Gara F, Morrissey JP. Applications of autofluorescent proteins for in situ studies in microbial ecology. Annu Rev Microbiol. 2005;59:257-77.

15. Tombolini R, Unge A, Davey ME, Bruijn FJ, Jansson JK. Flow cytometric and microscopic analysis of GFP-tagged Pseudomonas fluorescens bacteria. FEMS Microbiol Ecol. 1997;22(1):17-28.

16. Tombolini R, Jansson JK. Monitoring of GFP-tagged bacterial cells. In: LaRossa RA, editor. Bioluminescence methods and protocols. New York: Humana Press; 1998. p. 285-98.

17. Xi C, Lambrecht M, Vanderleyden J, Michiels J. Bi-functional gfp and gusA containing mini Tn5 transposon derivatives for combined gene expression and bacterial localization studies. J Microbiol Methods. 1999;35(1):85-92.

18. Compant S, Reiter B, Sessitsch A, Nowak J, Clément C, Barka EA. Endophytic colonization of Vitis vinifera $L$. by plant growth-promoting bacterium Burkholderia sp. strain PsJN. Appl Environ Microbiol. 2005;71(4):1685-93.

19. Baldan E, Nigris S, Populin F, Zottini M, Squartini A, Baldan B. Identification of culturable bacterial endophyte community isolated from tissues of Vitis vinifera 'Glera. Plant Biosyst. 2014;148:508-16.

20. Baldan E, Nigris S, Romualdi C, D'Alessandro S, Clocchiatti A, Zottini M, et al. Beneficial bacteria isolated from grapevine inner tissues shape Arabidopsis thaliana roots. PLoS One. 2015;10:10.

21. Xue GP, Johnson JS, Dalrymple BP. High osmolarity improves the electrotransformation efficiency of the gram-positive bacteria Bacillus subtilis and Bacillus licheniformis. J Microbiol Methods. 1999;34(3):183-91.

22. Murashige T, Skoog F. A revised medium for rapid growth and bio assays with tobacco tissue cultures. Physiol Plant. 1962;15(3):473-97.

23. Ge B, Liu B, Nwet T, Zhao W, Shi L, Zhang K. Bacillus methylotrophicus strain NKG-1, isolated from Changbai Mountain, China, has potential applications as a biofertilizer or biocontrol agent. PLoS One. 2016;11:11.

24. Oka K, Hirano T, Homma M, Hshii H, Murakami K, Mogami S, et al. Satisfactory separation and MS-MS spectrometry of six surfactins isolated from Bacillus subtilis natto. Chem Pharm Bull. 1993;41:1000-2.

25. Tang JS, Zhao F, Gao H, Dai Y, Yao ZH, Hong K, et al. Characterization and online detection of Surfactin isomers based on HPLC-MSn analyses and their inhibitory effects on the overproduction of nitric oxide and the release of TNF- $a$ and IL-6 in LPS-induced macrophages. Mar Drugs. 2010;8:2605-18.

26. Favaro G, Bogialli S, Di Gangi IM, Nigris S, Baldan E, Squartini A, Pastore P, et al. Characterization of lipopeptides produced by Bacillus licheniformis using liquid chromatography with accurate tandem mass spectrometry. Rapid Commun Mass Spectrom. 2016;30:2237-52.

27. Berg G, Krechel A, Ditz M, Sikora RA, Ulrich A, Hallmann J. Endophytic and ectophytic potato-associated bacterial communities differ in structure and antagonistic function against plant pathogenic fungi. FEMS Microbiol Ecol. 2005;51(2):215-29.

28. Wang $\mathrm{H}$, Wen $\mathrm{K}$, Zhao $\mathrm{X}$, Wang $\mathrm{X}$, Li A, Hong $\mathrm{H}$. The inhibitory activity of endophytic Bacillus sp. strain CHM1 against plant pathogenic fungi and its plant growth-promoting effect. Crop Prot. 2009;28(8):634-9.

29. Larignon P, Dubos B. Fungi associated with esca disease in grapevine. Eur J Plant Pathol. 1997;103:147-57.

30. Yacoub A, Gerbore J, Magnin N, Chambon P, Dufour MC, Corio-Costet MF, et al. Ability of Pythium oligandrum strains to protect Vitis vinifera L. by inducing plant resistance against Phaeomoniella chlamydospora, a pathogen involved in esca, a grapevine trunk disease. Biol Control. 2016;92:7-16.

31. Zhao $Y$, Selvaraj JN, Xing F, Zhou L, Wang Y, Song H, et al. Antagonistic action of Bacillus subtilis strain SG6 on Fusarium graminearum. PLoS One. 2014;9(3).

32. Li X, Zhang Y, Wei Z, Guan Z, Cai Y, Liao X. Antifungal activity of isolated Bacillus amyloliquefaciens SYBC H47 for the biocontrol of peach gummosis. PLoS One. 2016;11(9).

33. Brader G, Compant S, Mitter B, Trognitz F, Sessitsch A. Metabolic potential of endophytic bacteria. Curr Opin Biotech. 2014;27:30-7.

34. Madslien EH, Rønning HT, Lindbäck T, Hassel B, Andersson MA, Granum PE. Lichenysin is produced by most Bacillus licheniformis strains. J Appl Microbiol. 2013;115:1068-80.

35. Goswami D, Dhandhukia P, Patel P, Thakker JN. Screening of PGPR from saline desert of Kutch: growth promotion in Arachis hypogea by Bacillus licheniformis A2. Microbiol Res. 2014;169:66-75.

36. Chen Y, Liu SA, Mou H, Ma Y, Li M, Hu X. Characterization of Lipopeptide biosurfactants produced by Bacillus licheniformis MB01 from marine sediments. Front Microbiol. 2017;8:871.

37. Ongena M, Jacques P. Bacillus lipopeptides: versatile weapons for plant disease biocontrol. Trends Microbiol. 2008;16:115-25.

38. Falardeau J, Wise C, Novitsky L, Avis TJ. Ecological and mechanistic insights into the direct and indirect antimicrobial properties of Bacillus subtilis lipopeptides on plant pathogens. J Chem Ecol. 2013;39(7):869-78.

39. Farace $G$, Fernandez $O$, Jacquens L, Coutte F, Krier F, Jacques $P$, Clément $C$, et al. Cyclic lipopeptides from Bacillus subtilis activate distinct patterns of defence responses in grapevine. Mol Plant Pathol. 2015;16(2):177-87.

40. Leclère $V$, Marti $R$, Béchet $M$, Fickers $P$, Jacques $P$. The lipopeptides mycosubtilin and surfactin enhance spreading of Bacillus subtilis strains by their surface-active properties. Arch Microbiol. 2006;186:475-83.

41. Mitter B, Petric A, Shin MW, Chain PSG, Hauberg-Lotte L, Reinhold-Hurek B, et al. Comparative genome analysis of Burkholderia phytofirmans PsJN reveals a wide spectrum of endophytic lifestyles based on interaction strategies with host plants. Front Plant Sci. 2013;4:120.

42. Loaces I, Ferrando L, Fernández Scavino A. Dynamics, Diversity and function of endophytic Siderophore-producing Bacteria in Rice. Microb Ecol. 2011;61:606-18.

43. Richardson AE, Simpson RJ. Soil microorganisms mediating phosphorus availability update on microbial phosphorus. Plant Physio. 2011;156:989-96.

44. Sumi CD, Yang BW, Yeo IC, Hahm YT. Antimicrobial peptides of the genus Bacillus: a new era for antibiotics. Can J Microbiol. 2014;61(2):93-103.

45. Ryu CM, Farag MA, Hu CH, Reddy MS, Kloepper JW, Paré PW. Bacterial volatiles induce systemic resistance in Arabidopsis. Plant Physiol. 2004;134:1017-26.

46. Rudrappa T, Biedrzycki ML, Kunjeti SG, Donofrio NM, Czymmek KJ, Paré PW, Bais HP. The rhizobacterial elicitor acetoin induces systemic resistance in Arabidopsis thaliana. Commun Integr Biol. 2010;3(2):130-8.

47. Kong HG, Shin TS, Kim TH, Ryu CM. Stereoisomers of the bacterial volatile compound 2, 3-Butanediol differently elicit systemic defense responses of pepper against multiple viruses in the field. Front Plant Sci. 2018:9:90.

48. Xie SS, Wu HJ, Zang HY, Wu LM, Zhu QQ, Gao XW. Plant growth promotion by spermidine-producing Bacillus subtilis OKB105. MPMI. 2014;27(7):655-63.

\section{Ready to submit your research? Choose BMC and benefit from:}

- fast, convenient online submission

- thorough peer review by experienced researchers in your field

- rapid publication on acceptance

- support for research data, including large and complex data types

- gold Open Access which fosters wider collaboration and increased citations

- maximum visibility for your research: over $100 \mathrm{M}$ website views per year

At BMC, research is always in progress.

Learn more biomedcentral.com/submissions 